September 2007

\title{
Credit risk transfer, hedge funds and the supply of liquidity
}


The Author(s):

Prof. Dr. Heinz Zimmermann

Center of Business and Economics (WWZ), University of Basel

Department of Finance

Holbeinstrasse 12, CH-4051 Basel

heinz.zimmermann@unibas.ch

A publication oft the Center of Business and Economics (WWZ), University of Basel.

(C) WWZ Forum 2007 and the author(s). Reproduction for other purposes than the personal use needs the permission of the author(s).

\section{Contact:}

WWZ Forum | Petersgraben 51 | CH-4003 Basel | forum-wwz@unibas.ch |www.wwz.unibas.ch 
Credit risk transfer, hedge funds, and the supply of liquidity

\author{
Heinz Zimmermann* \\ Wirtschaftswissenschaftliches Zentrum WWZ \\ Universität Basel, Switzerland
}

September 2007

Revised version

Second International Conference on Law and Economics

29 June, 2007, St. Gallen, Switzerland

\begin{abstract}
This paper provides a discussion about some recent issues related to the transfer of credit risk (CRT) from the perspective of global liquidity. The CRT market is enormously growing and exhibits major structural shifts in terms of buyers and sellers of protection. I try to address these issues from an options perspective by suggesting that liquidity providing can be understood, in economic terms, as selling put options. The overall conclusion of the paper is that it is not the extent of CRT per se, as often claimed, which causes liquidity related systemic risk, but rather the potential coordination failures of the behavior market participants in adverse market environments. In this context, I critically address the role of investments banks in providing liquidity to hedge funds, and finally, the (limited) access of global banks to central bank liquidity through cross-border collateral trading. - Since coordination failures, seen as the major issue of a potential liquidity crisis, is to a large extent a matter of market structure, regulatory actions to improve liquidity should focus on the architecture of the financial system in the first place, not so much on the behavior of individual agents. Market stabilization should therefore be understood as a process of establishing informative markets and adequate infrastructure.
\end{abstract}

*heinz.zimmermann@unibas.ch

Holbeinstrasse 12

$\mathrm{CH} 4051$ Basel

I would like to thank Peter Nobel, Yvan Lengwiler and Yvonne Seiler for helpful discussions in preparing this paper. Geoffrey P. Miller added interesting and substantial comments as discussant at the Conference. They are not included in the present draft, but added as a separate contribution to this volume (???). 


\section{Motivation of this paper}

This paper should not be understood as an original academic contribution to the highly controversial topic of credit securitization, credit derivatives, its impact on systemic risk, financial stability and regulation. It is rather a review of several aspects of the current discussion from the perspective of global liquidity. I also try to review some of the relevant academic papers.

This perspective contrasts somehow the current discussion which strongly focuses on risk issues, such as risk transfer, risk measurement, disclosure, regulation - at least at first-sight. However, when it comes to asses the potential disruption of the market, or systemic issues, the discussion comes quickly down to "liquidity" issues, as the examples reproduced in the Appendix demonstrate.

Given its apparent importance, both in terms of financial stability and potential regulation, it is interesting to observe that there is neither a consistent terminology, nor a consistent framework to analyze liquidity issues. I try to address the issue from an options perspective by suggesting that liquidity providing is, in economic terms, the same as selling put options. This equivalence is motivated - although not explicitly proposed - by Grossman [1988] in the context of the equity market crash of 1987, and Scholes [2000] in discussing the near-collapse of LTCM.

I think that this provides a useful framework for addressing liquidity issues in general, and in particular, provides important insights when analyzing the credit risk transfer (CRT) markets and the role of investment banks, hedge funds, central banks, and other participants. Of course, these thoughts are preliminary and critical comments are welcome.

The rest of the paper is structured as follows: In Section 2, I shortly address the basic terminology related to CRT, and pro- 
vide some figures. Sections 3 and 4 show how the provision of liquidity, and the selling of insurance, is related to writing put options. In Sections 5 and 6 I analyze the economic function of CRT markets, particularly the problems related to over-thecounter products. Section 7 reviews some recent figures about the demand and supply of credit risk transfer. In Section 8 I discuss the role of hedge funds and investment banks as major players in the CRT markets, and in Section 9 I address the role of central banks, particularly their role as liquidity providers of last resort. Section 10 takes up some regulatory issues. Section 11 gives a selective review of the academic literature on the economic effects of CRT. Section 12 summarizes the main arguments discussed in this paper.

A final remark: This paper reflects the state of the discussion and perception of issues as of June 2007, the date of the Conference. This was well before the US mortgage crisis accentuated and the role of central banks in supplying enormous amounts of liquidity has been debated. At least, the recent crisis provides some evidence that the issues and concerns discussed in this paper are not too detached from reality. 


\section{Credit risk transfer: Securitization and derivatives}

The enormous growth of the credit transfer (CRT) market has been widely discussed. CRT instruments include a wide variety of products and financing patters; all this together is often called "credit securitization", but it is important to distinguish two types of products:

- Structured credit products (true-sale securitization) ${ }^{1}$ : such as Collateralized Debt Obligations (cash CDO), with CBO and CLO as special forms

- Credit derivatives (synthetic securitization) ${ }^{2}$ : such as Credit Default Swaps, Synthetic CDOs, Index Trades, Credit Linked Notes (CLN), Total Return Swaps (TRS), etc.; the Table of BBA provides details.

The mechanics and variety of products can be found in e.g. BIS (2003), Franke (2005), Culp (2006), Mengle (2007), and elsewhere. The major difference between the two groups is that CDOs represent a direct risk transfer while e.g. CDS is a contractual (therefore, synthetic) risk transfer with the debt remaining on the balance sheet of the bank.

Market participants are either buying or selling protection; a buyer of protection receives cash flows in a respectively defined credit loss event, while the seller has to pay. It should be noted this terminology applies to forward type products (e.g. swaps, index trading) as well as option like instruments (e.g. credit spread options) - actual or synthetic.

\footnotetext{
${ }^{1}$ Structured credit products transfer the credit risk associated with a portfolio of reference assets representing the collateral. They are mostly issued in several "tranches": An equity tranche, mezzanine tranche, senior tranche, super-senior tranche, and others.

${ }^{2}$ Credit derivatives are instruments that transfer part or all of the credit risk of obligations (individual, pools) with no transfer of the legal ownership of the underlying asset.
} 
Exhibit 1 displays the recent growth of the CRT market; notice that the CDOs are issued notional amounts, while credit derivatives represent notional values outstanding. Obviously, they cannot be compared. As of the end of 2006, a notional amount of approximately 1000 bn US cash CDO was outstanding ${ }^{3}$.

Exhibit 1 - The growth of the Credit Risk Transfer Markets: Cash CDOs and Credit Derivatives

\begin{tabular}{|l|l|r|r|}
\hline & $\begin{array}{l}\text { CDO (cash) } \\
\text { (bn USD, issued } \\
\text { notional) }\end{array}$ & $\begin{array}{l}\text { Credit Derivatives }^{\text {b }} \text { (bn } \\
\text { USD, notional out- } \\
\text { standing year-end) }\end{array}$ & \\
\hline & & 180 & \\
\hline 1996 & NA & 350 & \\
\hline 1998 & NA & 586 & \\
\hline 1999 & NA & 893 & \\
\hline 2000 & NA & $1^{\prime} 189$ & \\
\hline 2001 & NA & $1^{\prime} 952$ & \\
\hline 2002 & NA & $3^{\prime} 548$ & \\
\hline 2003 & NA & $5 ' 021$ & \\
\hline 2004 & 157 & NA & \\
\hline 2005 & 272 & $20^{\prime} 207$ & \\
\hline 2006 & 549 & $33^{\prime} 120$ & \\
\hline 2008 (est.) & & & \\
\hline
\end{tabular}

${ }^{a}$ Source: SIFMA

${ }^{\mathrm{b}}$ Source: BBA (Britisch Bankers Association (2006)

It is not the growth of the credit transfer market per se which gives raise to public concern, but issues related to the structure of the market (OTC), the diversity of products (liquidity, complexity), the quality of the underlying risks, and the role and quality of the major counterparties (banks, insurance companies, hedge funds).

A breakdown of the major credit derivatives can be found in the BBA survey; the most recent study lists 18 different products compared to just have a dozens six years ago. The following table displays the major categories:

\footnotetext{
${ }^{3}$ Source: CreditFluxData+
} 
Exhibit 2 Major Credit Derivatives

\begin{tabular}{|c|c|c|}
\hline $\begin{array}{l}\text { Credit derivatives (narrow } \\
\text { definition) }\end{array}$ & $\begin{array}{l}\text { Relative share of } \\
\text { total derivatives, as } \\
\text { of } 2000\end{array}$ & $\begin{array}{l}\text { Relative share of } \\
\text { total derivatives, as } \\
\text { of } 2006\end{array}$ \\
\hline CDS single name & $38.0 \%$ & $33 \%$ \\
\hline Basket products & 6 & $2 \%$ \\
\hline Full index trades & PNA & $30 \%$ \\
\hline Tranched index trades & PNA & $8 \%$ \\
\hline Synth CDO - fully funded & PNA & $4 \%$ \\
\hline Synth CDO - partially funded & PNA & $13 \%$ \\
\hline CLN & $10 \%$ & $3 \%$ \\
\hline Cred Spr Opt & $5 \%$ & $1 \%$ \\
\hline Equity linked & PNA & $0 \%$ \\
\hline Swaptions & PNA & $1 \%$ \\
\hline Others* & $41 \%$ & $6 \%$ \\
\hline
\end{tabular}

* asset swaps, portfolio CLOs, total return swaps

PNA means that the product did not exist in 2000.

Source: British Bankers Association (2006)

For example, index trades were inexistent in 2000 , while they represent $30 \%$ of the market share in $2006^{4}$.

We will discuss several of the structural characteristics later. Before, I would like to offer an economic framework to analyze risk and liquidity.

\section{Liquidity provision as selling put options}

The term "liquidity" has many faces, and the different usages of the term are hard to reconcile (see Zimmermann 2007 for examples). However - associating the creation of liquidity with selling put options has several advantages: it captures the following features:

\footnotetext{
${ }^{4}$ It allows investors to take long and short views on credit events or spreads on a diversified basis, in a much more flexible way than by trading individual bonds. For instance, with the TRAC-X contract gives an exposure to the 100 most liquid creditdefault swaps in North America, Europe, Asia, Japan and Australia.
} 
- the availability of a numéraire asset, mostly cash (legal currency)

- conditionality: the supply of liquidity conditional on bad economic states

- commitment: the obligation to supply liquidity, conditional upon the defined state, in exchange of an asset at specified conditions (exercise price, time horizon)

- the synthetic nature of put options: replication by a dynamic strategy, equivalent to a stop-loss strategy with dynamically adjusted floor (cushion)

To recapitulate, a short put option represents the commitment to buy a risky asset (or more generally: an underlying risk position) at a specific underlying price within or at the end of a specific time period. "Selling" a put option can mean different things, depending on the institutional or contractual framework:

If it is an effective option traded at an organized exchange, the liquidity provided by the short option writer is secured by the daily margin requirements of the exchange. Of course, the margin payments - and thus the liquidity provided by the seller increase as the option gets more in the money.

No such security exists for an OTC put option, so the availability of liquidity is exposed to counterparty risk. At best, the seller of the put option is hedged against the underlying risk, which is typically done by a dynamic strategy in the underlying risk asset (short) and the holding of cash (long). The mechanics is displayed with a numerical example in Exhibit 3 below.

This makes it transparent why a short put option position is equivalent to a dynamic, liquidity providing strategy: the seller commits to buy the risky asset (in CRT: the credit risk) in the bad state, and does so by increasing its leverage. As we will see, this is the typical behavior of hedge funds: highly leveraged sellers of deep-out-of-the money put options. But are they, effectively, providers of liquidity? Unlike as for exchange-traded options, the hedge funds only behave as if they would short 
puts. But effectively, they represent a counterparty risk for the long side of the transaction.

As long as the underlying market is "liquid" and the risky asset can be easily traded, the put option hedge is safe and the "liquidity" provided by the put option seller works well. However, under certain circumstances, it may be difficult for the option seller to adjust the hedge position, and/or to get the required funding for the adjustment. So, while the "short put analogy" works well, it also raises the following question: who is effectively providing the liquidity, given the leverage of the (replicating) position?

Exhibit 3 Put options, and how they are synthetically replicated

A) Short Put
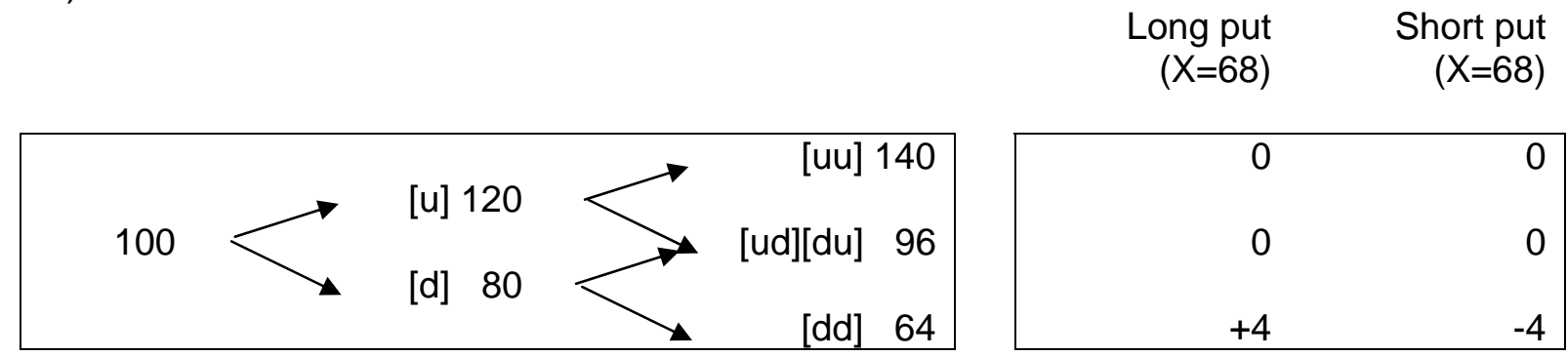

B) Synthetic Short Put

\begin{tabular}{rr|}
\hline - $^{*}$ ash & -6 \\
+ asset & +5 \\
\hline
\end{tabular}

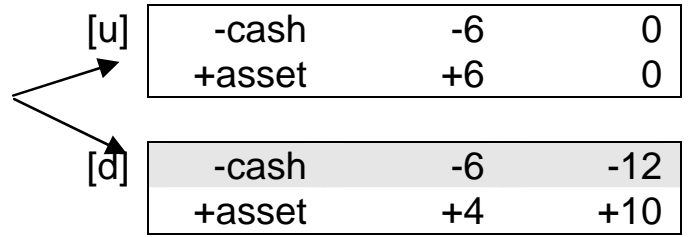

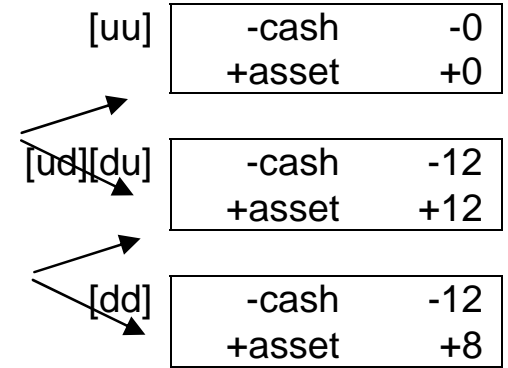

*a short position in cash is a fixed-rate loan (here: interest rate $=0 \%$ )

Explanation: Panel A displays a binomial ("up and down") price process over two periods. Three possible prices occur at the end of the second period $(64,96,140)$. The last two columns display the payoffs of a long and short put option with an exercise price of 68. Panel B shows how the value of the short put option (from Panel A) can be synthetically replicated with a long position in the underlying asset (positive sign) and a short position in cash (negative sign). The crucial point is the adjustment of the synthetic position after the first period: In the downstate, the long position in the asset must be increased (from 4 to 10), which is financed by an increase in leverage (from 6 to 12). 


\section{Applications}

The earliest notion that selling put options can be regarded as equivalent to the provision of liquidity, comes from Grossman [1988] - although he does not use the term explicitly: Dynamic portfolio insurance strategies ${ }^{5}$ were often regarded as a major driving force behind the stock market crash in 1987, because many institutional investors without having access to "aggregate information" about the actual use of similar strategies tried to manage the downside risk of their portfolio by a synthetic (dynamic) strategy. However, unlike with using actual put options, the implementation and success of a dynamic strategy require assumptions about parameters on the underlying market (e.g. volatility) which are not necessarily consistent with equilibrium. Grossman shows that the "informational externalities" created by this behavior can destabilize markets, i.e. give raise to an unexpected liquidity shortage in the market reflected in sharpe price adjustments in the underlying market. Using actual put options can be understood as a market mechanism which "prices" the demand and supply of protection ex ante, with high put option prices giving an incentive to market participants to sell options (commit to buy shares) and thereby providing "liquidity".

The link to liquidity is more directly established by Scholes [2000] in discussing the LTCM liquidity crisis. The key argument which is of interest here is that hedge funds, such as LTCM, are explicitly regarded as providers (sellers, suppliers) of liquidity:

LTCM was in the business of supplying liquidity at levels that were determined by its traders. In 1998, LTCM had large positions, concentrated in less liquid assets. As a result of the financial crisis, LTCM was forced to switch from being a large supplier to being a large demander of liquidity, at a cost that eliminated its capital. Scholes (2000), p. 17

This was motivated - as the author claims - because the number of liquidity suppliers on capital markets sharply decreased in the nineties, motivating (unregulated, long term oriented) inves-

\footnotetext{
${ }^{5}$ not to be confused with "program trading" as an automated strategy implementing stock index arbitrage with futures contracts.
} 
tors such as hedge funds to step in the market and earn a risk premium.

During the last two years, the number of liquidity providers diminished. Many financial institutions that previously devoted part of their capital to earning returns by supplying liquidity to the market withdrew from doing such or would only commit capital at much higher expected premiums. To provide liquidity, an investor must have a longer horizon than the average market participant. Scholes (2000), p. 17.

The risk premium, however, was regarded as extremely low, forcing investors to highly leverage their investment in order to get a "fair" premium:

Interestingly, because the liquidity premium is generally small relative lo the expected return on alternative investments, liquidity providers are generally leveraged investors that must hedge other factor exposures. Scholes (2000), p. 17.

Of course, from a risk-return perspective, there is no reason for leverage at all $(\mathrm{MM})$ - except in order to increase the expected rate of return.

The presumption of liquidity premiums being small is theoretically implausible and empirically not supported by the data. First, if the institutions supplying liquidity to the market effectively decreased over time, the premium should increase ceteris paribus. Indeed, a study of Pastor/ Stambaugh (2003) shows that the average liquidity premium (i.e. the average return spread between stocks with high sensitivities to liquidity and stocks with low sensitivities) is as high as $7.5 \%$ per annum over a 34-year period ${ }^{6}$; of course, this is not the market segment Scholes had in mind when discussing liquidity issues related to $\mathrm{LTCM}^{7}$. But at least in stock markets, liquidity risk is highly rewarded.

The important point for the subsequent discussion is that Scholes' characterization of liquidity and hedge fund behaviour is not a matter of the past, but still provides a highly adequate picture

\footnotetext{
${ }^{6}$ adjusted for exposures to the market return as well as size, value, and momentum factors.

${ }^{7}$ LTCM had illiquid foreign bond positions.
} 
of the hedge fund industry today. The following quote is from a recent study of Dresdner Kleinwort on the hedge fund industry ${ }^{8}$ :

"A clear majority of hedge funds can be thought of as leveraged sellers of deep-out-of-the-money put options. They employ long-short strategies - removing market risk with what are essentially spread or arbitrage bets with a relatively low return. To boost returns they employ extensive leverage. These spread positions do produce what look like low-risk returns most of the time but, once in a blue moon, what are effectively options written by the hedge funds will get called. Think LTCM." Dresdner Kleinwort "The Great Unwind is Coming", February 2007

The disturbing implication comes from the fact that hedge funds are heavily selling credit risk protection, and the leverage is substantially provided by investment banks - who in turn are becoming sellers of protection on their own. This will be illustrated below.

\footnotetext{
${ }^{8}$ Unfortunately, the study is not publicly accessible. The subsequent quote can be found in several commentaries
} of the study. 


\section{The economic function of credit risk transfer}

The typical function of CRT is seen in an improved, or at least facilitated, allocation (dispersion) of credit risk among a wider spectrum of market participants using capital markets. Sometime the function is characterized as transformation of "illiquid" balance sheet risk to "liquid" capital market risk.

Some clarification is required. From a capital market perspective, one has to distinguish between risk diversification and risk transfer. CRT is both: part of the credit risk can be diversified with other risks investors (insurance companies, pension plans) are exposed to; but obviously, part of the risk is systematic and thus priced with a premium. This makes it attractive for active risk trading (speculation), depending on the size and time variation of the premium.

In addition, essentially all CRT is allocated/ traded over-thecounter (OTC), i.e. outside organized derivatives markets. Thus, much of the concerns discussed before (informational externalities, lack of market prices) plus several operational problems are directly relevant here.

Again, the discussion and analysis provided by Scholes [2000] is directly relevant for the CRT market. Two arguments are key: First, most potential providers of liquidity use static stress-loss limits which are know to be time-inconsistent; they should optimally use dynamic stop-loss policies as e.g. implied by option replicating strategies.

Second, most potential risk takers do not know how the market price of liquidity affects the pricing of their stress-limits, which creates wrong capital allocation incentives. As a consequence

"because stress-loss cushions are static, entities have an ill-defined policy on when to supply and in what amounts. As a result, banks and financial entities are not the natural suppliers of liquidity...." Scholes (2000), p. 20. 
Whether these observations also apply to the current CRT products, is up for discussion. However, dynamic risk policies are virtually inexistent in, at least, the regulated financial sector, and reliable price information on the market price of liquidity is only imperfectly available. A recent market commentary claims:

The financial markets now are full of much liquidity. Are investors, speculators and their bankers appreciating and pricing in liquidity risk? Toomre Capital Markets LLC would suggest that liquidity risk presently is greatly under-valued in the search for "alpha", absolute return and portfolio yield. Lars Toomre, Hedge Funds, Investment Banks and the Value of Liquidity? 12/02/2007

This would require a centralized market for call and put options on credit risk with reliable price information. One might hope, as Scholes does, that

The financial industry will become more creative in supplying or finding a source of supply of "liquidity" options and contingent capital to supply liquidity in times of stress. As the reinsurance market has developed for excess loss, similar markets could develop and add value in financial markets. This becomes an important role for alternative investments. Scholes (2000), p. 21.

The analogy with the reinsurance market is particularly insightful. It highlights the role of reinsurance companies as liquidity provides to the direct insurers. However, the statement may be too optimistic about the potential role of hedge funds, and other alternative (unregulated) investors about their role in providing this function.

\section{Exchange-traded credit derivatives?}

Organized trading (standardization) of credit risk is just in the early stages. Eurex launched the world's first exchange-traded credit derivative contract, a futures based on the Itraxx Europe index, on March 27, 2007. It seeks to replicate the risk structure of CDS traded in the OTC market. To date, the success is however modest. 
Plans in the US are under review at the SEC: CME announced plans to list a credit derivative future on 3 single name CDS; also, CBOE has plans to launch credit default options on about 10 single names. As noted by Pool/ Mettler (2007), innovation is not expected to be substantial in a dealer dominated market structure like the US.

Of course exchange-traded credit derivatives would solve many of the problems with respect to transparency, pricing, margin requirements, and obviously, many of the operational risks inherent in the current market structure. The latter risks are perceived to be the most changeling ones by the major market participants:

Exhibit 4 The Challenges in CRT - as seen by the major market participants

\begin{tabular}{|l|r|r|}
\hline & Total & Banks only \\
\hline & & 22 \\
\hline Settlement & 17 & 18 \\
\hline Confirmations & 9 & 14 \\
\hline Documentation & 9 & 3 \\
\hline Liquidity & 8 & 7 \\
\hline Pricing & 8 & 4 \\
\hline Transparency & 6 & 5 \\
\hline Accounting & 6 & 3 \\
\hline Regulation & 6 & 5 \\
\hline Systemic Risk & 6 & 2 \\
\hline Tight Spreads & & 4 \\
\hline & & \\
\hline
\end{tabular}

Fitch 2006, p.2

The same finding emerges from the BAA survey, where "systems/ infrastructure is deemed to be the main drag on the market" (p. 33). 


\section{Demand and supply of credit protection: Some recent figures}

The determinants of demand and supply of credit protection, their size and predictability, is of major importance for systemic stability. Two sources provide up-to-date information about this: FitchRatings (Fitch) in their annual Global Credit Derivatives Survey, and the annual Credit Derivatives Report released by the British Bankers Association (BBA).

The 2006 Fitch report is based on a survey of 75 major institutions worldwide, with data/ information as of 2005. Among the most important findings are:

- From the reported institutions, there is a net difference between protection buyers and sellers of 377 bn USD. This gap reflects the presence of institutions not captured by the survey, namely hedge funds, pension funds, asset management companies.

Exhibit 5 Credit Protection Buyers and Sellers

\begin{tabular}{|l|l|l|l|l|}
\hline & $\begin{array}{l}\text { Protection } \\
\text { buyer }\end{array}$ & $\begin{array}{l}\text { Protection } \\
\text { seller }\end{array}$ & Gap & \\
\hline 2004 & Major: & Major: & 128 bn & \\
Banks: 427 bn & ?? & Major: & 377 bn & \\
\hline 2006 & $\begin{array}{l}\text { Major: } \\
\text { Banks: } 268 \text { bn }\end{array}$ & $\begin{array}{l}\text { Insurance/ Fin } \\
\text { Gurant: } 645 \text { bn }\end{array}$ & & \\
\hline
\end{tabular}

Fitch 2006, notional amounts, USD

- Banks: On a global basis, banks are still net buyers of protection (268 bn). However, many large European banks moved from net buyers to flat or even protection sellers (Fitch, p. 2); this shift is triggered particularly by three globally large UK and Swiss banks. The reason is seen in the growing importance of trading/market making, and the usage of credit derivatives for yield enhancement strate- 
gies, instead of classical hedging loan portfolios. This is also reflected in the following Table, adapted from BBA, which confirms that market making/trading is the prime motivating factor driving the usage of credit derivatives. The management of credit lines or of regulatory/ economic capital are relatively unimportant.

Exhibit 6 Usage of credit derivatives: Main motivation

\begin{tabular}{|l|l|l|}
\hline & 2002 - Rank & 2006 - Rank \\
\hline Trading/ market making & & 1 \\
\hline Product structuring & 1 & 2 \\
\hline Hedging trading instruments & 4 & 3 \\
\hline Active portfolio/ asset mgmt & 6 & 4 \\
\hline Mgmt individual credit lines & 5 & 5 \\
\hline Mgmt of regulatory capital & 2 & 6 \\
\hline Mgmt of economic capital & 3 & 7 \\
\hline
\end{tabular}

Source: BBA 2006

- Insurers/reinsurers plus financial guarantors sold protection amounting 645 bn USD ${ }^{9}$. On a net basis, credit derivatives are mainly used as alternative investments vehicles not for trading purposes, or market making. Interestingly, in terms of quality, $91 \%$ of the protection (sold by insurers) is in the AAA segment! These structural characteristics are in sharp contrast to the usage in banks or hedge funds.

- Counterparty concentration. Fitch reports that $86 \%$ of the trading volume (and $66 \%$ of the total exposure ${ }^{10}$ ) concentrates on the top 10 market makers. UBS is among the top 5 counterparties, and exhibits the best rating (AA plus) ${ }^{11}$. This concentration

\footnotetext{
${ }^{9}$ Notice that the figures are largely determined by AIG Financial Products' dominating activities in this market segment, which accounts for about $70 \%$ of the global net sold exposures.

${ }^{10}$ This figure is based on a purely count basis, i.e. how many times an institution was cited, and it thus an imperfect estimate of the economic exposure.

${ }^{11}$ Morgan Stanley AA-, Deutsche Bank AA-, Goldman Sachs AA-, JPMorgan Case A+.
} 
"... raises concerns about liquidity being maintained in the event one of these banks exiting the market either for idiosyncratic or exogeneous reasons" (p. 7).

“... heightens the potential for liquidity disruptions across the industry. For example, the market could be susceptible to a sharp unwinding or de-leveraging of positions across multiple firms" (p. 8).

The major shift in market participation over the past few years is the increased role of non-bank institutions, non-regulated institutions, particularly hedge funds. This comes clearly out from the following table adapted from the BBA-survey:

Exhibit $7 \quad$ Credit derivatives, shares of protection bought and sold

\begin{tabular}{|c|c|c|c|c|}
\hline 2006 & & $\begin{array}{r}\text { Buyers of pro- } \\
\text { tection }\end{array}$ & $\begin{array}{r}\text { Sellers of pro- } \\
\text { tection }\end{array}$ & Net \\
\hline \multirow{4}{*}{$\begin{array}{l}\text { Banks incl. securi- } \\
\text { ties firms }\end{array}$} & & & & \\
\hline & & $59 \%$ & $44 \%$ & $+15 \%$ \\
\hline & Trading & $(39 \%)$ & $(35 \%)$ & $(+4 \%)$ \\
\hline & Loan portfolio & $(20 \%)$ & $(9 \%)$ & $(+11 \%)$ \\
\hline \multirow[t]{2}{*}{ Insurers } & & $6 \%$ & $17 \%$ & $-11 \%$ \\
\hline & Reinsurance & $(2 \%)$ & $(4 \%)$ & $(-2 \%)$ \\
\hline Hedge Funds & & $28 \%$ & $32 \%$ & $-4 \%$ \\
\hline Pension funds & & $2 \%$ & $4 \%$ & $-2 \%$ \\
\hline Mutual funds & & $2 \%$ & $3 \%$ & $-1 \%$ \\
\hline Corporates & & $2 \%$ & $1 \%$ & $+1 \%$ \\
\hline Other & & $1 \%$ & $1 \%$ & $0 \%$ \\
\hline Total & & $100 \%$ & $100 \%$ & $0 \%$ \\
\hline
\end{tabular}

Source: British Bankers Association (2006)

Apparently, hedge funds clearly dominate insurers as sellers of protection (32\% vs. $17 \%)$. However, on a net basis, insurers are still the largest sellers of protection (-11\%), compared to hedge funds (-4\%). Interestingly, the net position of reinsurers has the same sign (net seller), and only accounts for a small fraction of the net overall position (-2\%). The figures corresponds to the net position taken by pension funds $(-2 \%)$.

Apparently, the role of hedge funds is particularly important. The following observations are revealing (Fitch 2005, Fitch 2006): 
- Hedge fund trading activity in credit derivatives is estimated at $20-30 \%$ of the global volume (which is lower than the $50 \%$ estimated by Greenwich Assoc.).

- Demand for higher yielding instruments increased in the past years. One third (!) of the protection sold in 2005 is in the speculative grade or unrated segment. Hedge funds particularly sell protection for below-investment grade credits (p. 2). Explicitly,

"some hedge funds now play a critical role in financing the least liquid, highest yielding subordinated tranches of transactions" (Fitch 2005, p. 4).

This observation has strong implications for role of rating agencies, both with respect to risk management and pricing, and finally, regulatory treatment of hedge funds as counterparties of regulated institutions.

\section{The Role of Hedge Funds and Investment Banks}

The link between banks and hedge funds (HFs) needs some analysis ${ }^{12}$. Apparently, the large banks face not only a substantial counterparty risk vis-à-vis HFs, but there is also a strong economic dependence with respect to the profitability of the HF industry as a whole. This relationship largely depends on the prime brokerage business, which is a package of services offered by investment banks to hedge funds: it includes financing services (leverage of HFs' assets), securities lending, trading, global custody services, operational support, consolidated cash management, risk management advisory and other services. The apparent advantage of using a prime broker for a hedge fund is the ability to keep trading relationship with multiple brokers while maintaining, in a centralized master account at their prime broker, the hedge fund's cash and securities/ collateral.

\footnotetext{
${ }^{12}$ A detailed analysis of these issues is provided by Cole/ Feldberg/ Lynch (2007).
} 
For the investment banks, the income generated through prime brokerage for hedge funds is substantial. According to various sources (see Mustier/ Dubois 2007 for a summary of the following figures), hedge funds generated as of 2005

- $40 \%$ of total equities trading revenues of investments banks, $20 \%$ of total fixed income trading revenues, and $80 \%$ of trading in distressed debt markets;

- USD 25.8 bn (or approx. 25\%) revenues, of which 8.8 bn (35\%) comes from prime brokerage. A detailed breakdown of the revenues is displayed in Exhibit 8.

Exhibit 8 Investment Banks Revenues generated by HFs: Estimates 2005

\begin{tabular}{|c|c|c|c|c|}
\hline $\begin{array}{l}\text { Total esti- } \\
\text { mated reve- } \\
\text { nues }\end{array}$ & & & & 25.8 \\
\hline \multirow[t]{7}{*}{ Of which... } & $\begin{array}{l}\text { Sales and } \\
\text { trading }\end{array}$ & & & 17.0 \\
\hline & $\begin{array}{l}\text { Prime broker- } \\
\text { age }\end{array}$ & & & 8.8 \\
\hline & Of which... & $\begin{array}{l}\text { Clearing and } \\
\text { custody }\end{array}$ & & 1.2 \\
\hline & & $\begin{array}{l}\text { Trading and } \\
\text { execution }\end{array}$ & & 3.4 \\
\hline & & Financing & & 4.2 \\
\hline & & Of which ... & Sec. Lending & 3.3 \\
\hline & & & Margin Lending & 0.9 \\
\hline
\end{tabular}

Various sources (see e.g. Mustier/ Dubois 2007)

Unfortunately, I found no figures showing the revenue share generated by credit derivatives, specifically.

However, in order to understand the potential risks emerging from the relationship between the banking sector and HFs, it is important to recognize that the most important source of income comes from the financing/ lending activities. Financing and lending fees are charged in bps of the value of loans to/ depos- 
its from HFs, securities lending (short sales), and synthetic financing products.

As a consequence, HFs with substantial short-selling and leverage create the most lucrative income opportunities for investment banks. The implied incentives for the banks are obvious. For the HFs, this behavior is highly attractive because it allows to leverage-up the tight credit spreads having emerged in this highly competitive market.

Of course, the lending to HFs is secured by margins or collaterals, but this (at least the latter) merely shifts the counterparty (credit) risk to market risk, and the problem is that the conditional value of collaterals in bad states is difficult to assess ex ante.

In our earlier interpretation, the option of HFs to shift their obligation away to the sponsoring banks implies that not the HF industry but rather the banking sector is effectively selling liquidity. However, as in dynamic portfolio insurance - the real (equilibrium) cost of insurance (liquidity) is not reflected in market prices - it can just estimated. But maybe that the estimate is way too low, and as in the case of LTCM in the statement of Scholes, the banks learn about the effective costs only after a shock to the system occurs.

The systemic implications of all that have now been recognized and lead to some concern; for example:

In effect, risks that, in theory, have been dispersed throughout the capital markets via disintermediation may, in fact, have become reconcentrated by some hedge funds." (Fitch 2005).

A recent study by Dresdner Kleinwort reaches similar conclusions:

While hedge fund strategies across the industry may look diversified, there is actually a high degree of correlation, since many funds are effectively running leveraged bets on stable or tightening risk premia. Any widening of risk premia will force large-scale liquidations of positions, with margin calls by the banks and redemptions by investors reinforcing the process. (Dresdner Kleinwort 2007) 
Of course, the potential systemic risk of credit derivatives is not limited to the bank-HFs relationship, but should include the role of re/insurance companies as sellers of protection as well: their hedging behavior, liquidity management strategies, and so on.

The systemic risk implied by credit derivatives is discussed in a series of theoretical papers (see the final section of this paper). A particularly interesting study (Allen/ Carletti 2006) investigates the contagion effects if banks and insurance companies issue credit derivatives and hold the same assets (collateral) as a hedge against liquidity risk - although for different reasons. Contagion occurs because there are states of nature where banks and insurance companies have to liquidate the collateral simultaneously. So, although the credit derivative improves the allocation of risk, it creates a potential systemic risk. The overall welfare effect is not easy to determine in general.

So, the conclusions are in line with the informal reasoning of the previously quoted concerns.

\section{Key Issue: The Role of Central Banks}

In my view, the biggest liquidity risk emerging from the CRT market is concentrated with the big banks: this is related,

- on the one hand, to their own trading positions, and

- on the other hand, to the various HF activities, based on which they face a substantial counterparty or liquidity risk related to the holding of client's collaterals, but also because their earnings increasingly depend on the performance and profitability of the HF industry.

But of course, the banks hedge the liquidity risks in various ways, and the key role is the role of collateral trading in their daily liquidity management. The role of the central bank(s) is 
crucial in this process ${ }^{13}$. Collateral trading provides access to contingent sources of liquidity at pre-announced terms, which is - apparently again - a sale of put options on the part of central banks. The monetary authority provides legal currency in exchange of a defined pool of "eligible" assets. Having access to standing facilities may help to stabilize markets exactly as in the portfolio insurance example, because it prevents the unexpected and uncoordinated sale of assets in periods of market disruption. Peaks in liquidity are likely to increase in the future, due to the emergence of complex international payment and settlement systems (e.g. CLS in the forex area).

The crucial question now is how the range of eligible assets is defined. For internationally active banks, restricting the pool to domestic assets (debt) is definitively too tight, and the direct access to central banks in other jurisdiction is operationally and legally restricted. So, the definition of an adequate, broadenough "pool" of pledgeable assets is of prime importance (see Exhibit ... for some evidence on this). However, no common approach to liquidity standards exists among central banks.

Even more importantly, in order to facilitate the cross-border liquidity management of global banks, ways should be established to pledge domestic collateral to a central bank in a different country. This requires the implementation of "routine" (as opposed to exceptional) cross-border collateral arrangements between the major central banks. For instance

For example, the Bank of England routinely employs such arrangements to accept euro-denominated government securities as collateral for sterling liquidity, and also stands ready to accept US Treasuries in exceptional circumstances. (Bank of England 2007), p. 52, italics by the author.

Establishing cross-border collateral arrangements would provide indeed an "efficient liquidity bridge across markets" (BISCPSS, 2006, p. 16).

\footnotetext{
${ }^{13}$ an up-to-date discussion of these issues can be found in the 2007 Financial Stability Report of the Bank of England.
} 
However, the current practice is still far away from that. An indepth analysis of the practices and procedures used by international banks in their liquidity and collateral management is provided by a Working Group of the BIS Committee on Payment and Settlement Systems (CPSS), reviewing the practices of 30 international banks in the G10 countries; see Figure 1 von $p$. 12. The study reveals that only a small minority of banks (2!) have actually implemented a globally integrated, centralized basis with a direct access to foreign markets (so called selfclearing). Interestingly, several banks even argue that they prefer decentralized liquidity and collateral management, "ensuring diversification of collateral/liquidity holdings/sources in the event of an emergency" (p. 11). There is, obviously, a tradeoff between efficiency and systemic safety which is difficult to balance.

Overall, the extent to which major investment banks faces collateral constraints in their global liquidity management, and the degree to which these may be mitigated by a more efficient cross-border use of collateral, becomes an increasingly important topic in the future: the risk allocation and liquidity effects of credit derivatives and the de/stabilizing role of hedge funds crucially depends on the liquidity provision of the monetary authorities, i.e. their willingness to write put options on a pool of assets. More effort is necessary to keep up with the dramatic growth of these complex markets.

Exhibit 9 The impact of central bank eligible collateral: Average daily usage, in \% of outstanding collateral, to meet banks' demand for central bank liquidity

\begin{tabular}{|l|r|r|r|r|r|}
\hline & $\begin{array}{l}\text { Domestic } \\
\text { debt only }\end{array}$ & & $\begin{array}{l}\text { Total eligi- } \\
\text { ble assets }\end{array}$ & \\
\hline Sweden & & $11 \%$ & & $<1.0 \%$ & \\
\hline Switzerland & $15 \%$ & & $1.0 \%$ & \\
\hline UK & $30 \%$ & & $3.5 \%$ & \\
\hline
\end{tabular}

Source: BIS 2006 (Bank of International Settlements BIS, 2006, Cross-border collateral arrangements), p. 9 


\section{Regulatory actions?}

Regulators, monetary authorities, financial stabilizators, and academics have become well aware of the issues discussed before. However, much of the discussion is still concerned about market discipline, disclosure and transparency, stress testing and the like (see Weber 2007, Cole/Feldberg/Lynch 2007 and other contributions in the same volume). For instance, the Swiss National Bank (see Hildebrand 2007), in its "bestpractice proposal", aims at strengthening the credit relationship between prime-brokers and hedge funds, and suggests to take stress tests and liquidity risk seriously.

"The underlying liquidity profile of hedge funds should be an important element in conducting stress tests and margin call simulations as well as in determining margin call procedures under adverse market conditions." Hildebrand (2007)

However, the concern of Myron Scholes still applies, namely that stress tests remain a "dry run" as long as they are not priced with market data: the relevant question is how the market price of liquidity affects the pricing of their stress-limits, or what it would cost for the banks to buy excess loss (re)insurance for these limits.

Perhaps the analogy of a liquidity crisis with traffic jam may help more to clarify the point (see Zimmermann 2007). The question is whether a traffic jam (say, on a highway) is the consequence of

- insufficient capacity? (need for more lines, more highways)

- insufficient advance information (transparency)? (everybody using GPS)

- insufficient coordination! Coordination can be improved by a. regulatory action (harmonization of behavior): Break lights, minimum distance, speed range, ... 
b. market structure design: order systems, settlement systems, financial instruments, etc. aggregating individual plans and expectations and thereby providing due-time information about prospective market imbalances and traffic jam in the financial system.

Markets are typically regarded as an extremely efficient mechanism to coordinate decisions: This is the old claim by Hayek (1945), that prices help individuals making informative decisions in spite of their limited overall information about the structure of the economic system.

What is operationally difficult for roads (real-time road-pricing) is much easier for financial markets: Liquidity, in principle, can be easily priced, even real-time; we just need appropriate instruments, organized exchanges and efficient infrastructures (for a conceptual proposal, see Black 1995).

Summing up:

- It's not the extent of CRT per se, as often claimed, which causes liquidity related systemic risk, but rather the potential coordination failures of the behavior market participants.

- Coordination issues are, to a large extent, a matter of market structure; thus regulatory actions aimed at improving liquidity should focus on the architecture of the financial system, not so much on the behavior of individual agents (such as the Basel II capital standards) ${ }^{14}$.

- Market stabilization should therefore be understood as a process of establishing informative markets and adequate infrastructure.

\footnotetext{
${ }^{14}$ See Eichenberger/Summer (2005) for a similar argument: "If regulation aims at the risk allocation in the entire banking system, then it has to depart from concentrating on individual bank balance sheets. (...) A system approach to banking regulation is the beginning” (p. 24).
} 


\section{A selective literature review on CRT}

There is not a vast literature analyzing the role of credit derivatives in a broader economic setting. There are only a few models, and even less empirical work. In this section I shortly review several papers which I find particularly interesting. Of course, this review is far from complete.

Allen/ Carletti (2006) develop a model with a banking and insurance sector; they demonstrate that if banks face idiosyncratic (heterogeneous) liquidity risk and hedge this risk in an interbank market, CRT can be welfare reducing. "It can lead to contagion between the two sectors and increase the risk of crises." In the model, both banks and insurance companies use the same asset (called a long term asset) as hedge: the banks as hedge against idiosynchratic liquidity risk, and insurance companies as hedge against CRT (i.e. the credit risk they buy from the banks). If insurance companies earn insufficient premia to cover firms' losses, they have to sell the long asset at a discount, which in turn deteriorates the value of the banks' hedge against liquidity risk. So banks may suffer liquidity risk and bankrupt. The model is slightly superficial and does not relate well to the real world of CRT. At least, some interesting remarks can be found at the end of the paper (see the quotes C3 and $\mathrm{C} 4$ in the Appendix).

Morrison (2005) demonstrates that CRT destroys the signalling role of bank debt, and thus, leads to an overall reduction in welfare. Whether disclosure requirements for credit derivatives are sufficient to help to offset this effect (as suggested) is questionable.

Parlour/ Plantin (2005) analyze adverse selection problems associated with CRT. While providing more flexibility for banks to recycle capital, CRT markets "may also reduce a bank's incentive to monitor as it could also sell non-performing loans. The 
impact of the credit risk transfer market on banks and capital markets depends on this tradeoff between a lower monitoring incentive and the increased flexibility offered by a liquid market." Therefore, CRT is socially efficient ex post (i.e. given that it exists), but not necessarily ex ante.

Wagner (2005) shows that enhanced diversification of credit risk exhibits a trade-off: while reducing each institution's individual probability of default, banks could be induced to increase their investment in risky assets at the cost of their liquidity holding, which can increase the probability of a liquidity-based crisis.

Duffee/ Zhou (2001) argue that while credit derivatives may improve capital allocation for banks, the overall effect can be negative because other risk sharing markets, such as direct loan sales, can potentially break down: if banks use credit derivatives to sell part their loan portfolio, this could alter investors' expectations about the loan quality sold in the loan-sale market, worsening the adverse selection problem to such an extent that it collapses.

On the empirical side, Goderis/ Marsh/ Vall Castello/ Wagner (2006) find that banks issuing CDOs (at least once) experience a permanent increase in their target loan levels of around 50\%.

Krahnen/ Wilde (2006) investigate the impact to credit securitization (CDOs) on the cyclicality of banks, as measure by banks' equity returns. Modelling the subordination of tranches and the capital structure of banks, they find that the banks' systematic risk tends to increase. 


\section{Conclusions}

I would like to summarize the major insights of this memorandum as follows:

1) In principle, credit risk transfer (CRT) facilitates the distribution of credit risk. We argue that selling CRT protection is equivalent to improving the liquidity of the financial system. It's like selling portfolio insurance.

2) In terms of the overall financial disintermediation process being accelerated with the CRT markets, one should differentiate between capacity effects (e.g. infrastructure, market making), information effects (e.g. transparency, disclosure, adverse selection), and coordination. The focus of my analysis is on the latter.

3) Hedge funds take increasingly the role of protection sellers in this market; they can be characterized as highly leveraged sellers of deep out-of the money puts. But this is not done through actual put options (firm commitment, margins), but synthetically. Therefore their commitment is questionable - apparently (as revealed by the Scholes quote), they easily shift from providing to demanding protection in the relevant state of nature. The Scholes quote refers to a market environment without the huge credit derivatives market. The question is whether the market structure, in terms of demand and supply of liquidity, is more stable today.

Under these circumstances, given that the entire CRT market operates over-the-counter, it is difficult to find out "who is doing what" in a market disruption. Therefore, the role of hedge funds in providing "liquidity" is questionable. 
4) So the key issue becomes who is providing the "liquidity" to the hedge funds. The Prime Brokerage Business of investment banks facilitates leveraging the funds, primarily through margin and securities lending. To the extent that investment banks provide the capital, they are effectively the protection sellers. Therefore the key question is how the banks manage their own liquidity risk.

5) As further observation, the trading departments of investments banks increasingly sell credit protection on their own.

6) A natural question arising from all this is the role of central banks as "liquidity providers of last resort"; they do this by selling put option to the banks, called collateralized trading. This provides the major banks of a jurisdiction access to contingent sources of liquidity at pre-announced terms. The critical question is, however, how much they should commit, and how they evaluate the value of collaterals. In particular, across currencies (jurisdictions?), collateralized trading is still restricted, although arrangements between central banks are being developed (or at least, discussed) to improve the cross-border use of collateral. But still, this is in my view a key liquidity constraint of the financial system.

7) There are many open questions: What is the systemic impact of ratings, of the rating industry? What is the role of the insurance/ reinsurance industry as liquidity providers?

8) The overall conclusion of this paper is, that it is not the extent of CRT per se, as often claimed, which causes liquidity related systemic risk, but rather the potential coordination failures of the behavior market participants in adverse market environments.

9) Coordination issues are, to a large extent, a matter of market structure; thus regulatory actions to improve liquid- 
ity should focus on the architecture of the financial system in the first place, not so much on the behavior of individual agents. Market stabilization should therefore be understood as a process of establishing informative markets and adequate infrastructure: CRT products, particularly options, should be traded at derivatives exchanges, so that selling protection is transparent, both in terms of counterparty risk and pricing (adequate margins, daily settlement).

10) The regulator's agenda in the post-Basel II era should therefore include a conceptual framework to analyze liquidity issues in a broad, but unified context, including all major financial intermediaries (including central banks, re/insurance, hedge funds, pension funds, clearing organizations, etc.). 


\section{Appendix:}

The current discussion about credit securitization, credit derivatives, hedge funds, and liquidity

\section{In this appendix, we list several quotes related to our discussion in the text.}

\section{A) Public discussion, newspapers, rating agencies, and market commentaries}

A1) David Roche, of Independent Strategy, argues that derivatives have created a form of liquidity outside the control of central bankers. "It is pretty obvious that if one can buy a security that represents an asset for 3-5\% of its value, an awful lot of liquidity has been freed up," he says. Economist, April 19 $9^{\text {th }}, 2007$ "At the risky end of finance"

A2) Credit has a paradoxical effect on stability. Although debt and leverage raise the level of risk, credit provides the markets with liquidity that serves to dampen volatility. (...) Edward Chancellor, Ponzi nation, 2/7/2007

A3) In Fitch's opinion, potential ratings volatility would be felt most in the high yield sector and among borderline investment grade companies due to their sensitivity to liquidity access and refinancing risk. The timing of such a liquidity event would be a determinant factor. Fitch, Hedge Funds: An Emerging Force in the Global Credit Markets, 2005, p. 7

A4) The relative concentration of market makers and counterparties also heightens the potential for liquidity disruptions across the industry. For example, the market could be susceptible to a sharp unwinding or de-leveraging of positions across multiple firms. Fitch, Gloval Credit Derivatives Survey, 2006, p. 7-8

\section{B) IMF, BIS, Central Banks}

B1) With the growth of hedge funds, banks and other buyers of credit protection have realized a much greater ability to transfer credit risk, particularly the sale of equity or "first loss" tranches. These developments have also improved liquidity in credit derivative markets in recent years. IMF (2006), p. 56

B2) However, once transferred, secondary market liquidity risks and related contagion effects remain, and may constitute the most significant stability risk emanating from the structured credit markets. Evaluating, managing, and ultimately reducing liquidity risk is a key challenge for investors, as well as for supervisors and other public officials concerned with financial stability. IMF (2006), p. 66 
B3) In such markets [if there is a lack of diversity among market participants], actual liquidity tends to fall well short of perceived or anticipated liquidity, and can lead to more volatile markets, liquidity disruptions, and price gapping. Increasing the diversity of market participants is important to maintain two-way flows and relatively stable liquidity conditions. IMF (2006), p. 66

B4) Liquidity risk might also become more important, created either by contingent liabilities within securitisation structures or by increased dependence on these transactions as a funding device. These risks are more difficult to measure than credit and market risk, and it may be difficult to deal with them in quantitative capital rules and disclosure standards. Bank for International Settlements (2003), p. 28.

B5) The main concern with regard to financial stability is that failures of one or more larger hedge funds might jeopardise the stability of major complex financial institutions and/or create market liquidity crises. Weber, Deutsche Bundesbank (2007)

\section{C) Academic papers}

C1) The result has been that credit has gradually changed from an illiquid risk that was not considered suitable for trading to a risk that can be traded much the same as others. (...) Hedge funds use credit derivatives in a variety of ways, all of which tend to augment market efficiency and price discovery as well as to increase liquidity. Mengle (2007)

C2) With some qualifications, our analysis may hence also apply to other financial institutions, such, for example, insurance companies or hedge funds. Their failure induces similar costs, for instance because assets can only be liquidated at an inferior price. Moreover, they are also likely to suffer from being in a crisis jointly. For example, because they rely on a common pool of liquidity they may find it more difficult to liquidate assets at a fair price (as in our setup) or to borrow funds in crisis times. Wagner (2005), Diversification, no date

C3) The interaction of incomplete markets and the role of liquidity in asset pricing are the key factors for the contagion across sectors. These elements can occur in the context of many financial institutions. Hedge funds have become increasingly important in many markets. They potentially provide a conduit for contagion across many illiquid markets. Allen/ Carletti (2006), p. 110

C4) This paper has focused on the private provision of liquidity in markets and has not analyzed the role of central banks in liquidity provision. In markets with limited participation it is likely that central banks will have problems injecting liquidity into the financial system that will reach the required markets and prevent the kind of contagion considered here. Allen/ Carletti (2006), p. 110

C5) However, a liquid CRT market may also reduce a bank's incentive to monitor as it could also sell non-performing loans. The impact of the credit risk transfer market on banks and capital markets depends on this tradeoff between a lower monitoring 
incentive and the increased flexibility offered by a liquid market. Parlour/ Plantin (2005)

C6) The secondary market for customized CDOs is nonexistent. One potential concern is that some participants in credit derivatives markets may overestimate the liquidity of these products in constructing and hedging their correlation based portfolios. The issue is not whether occasional losses are sustained by well-diversified large investors, but rather that one of the key player's portfolios may be too highly concentrated in these instruments. While CDS indices have a certain level of liquidity due to their standard nature, they are not perfect hedges, and thus give rise to basis risk. Chan-Lau/ Ong (2006) 


\section{References}

Allen, F. and E. Carletti, 2006, Credit risk trans and contagion, Journal of Monetary Economics 53, pp. 89-111.

Bank of England, 2007, Financial Stability Report, Issue No.21, April 2007

Baur, D. and E. Joossens, 2006, The effect of credit risk transfer on financial stability, Working Paper

Bank of International Settlements BIS, 2001, Core Principles for Systemically Important Payment Systems, CPSS Publications No 43, Basel.

Bank of International Settlements BIS, 2003, Credit Risk Transfer. Committee on the Global Financial System, BIS, Basel.

Bank of International Settlements BIS, 2005, The role of ratings in structured finance: issues and implications. Committee on the Global Financial System, BIS, Basel.

Bank of International Settlements BIS, 2006, Cross-border collateral arrangements, Committee on Payment and Settlement Systems, January 2006

Black, F., 1995, Equilibrium Exchanges, Financial Analysts Journal 51 (May/June), pp. 23-29.

British Bankers Association (BBA), 2006, Credit Derivatives Report, British Bankers Association.

Cole, R., G. Feldberg and D. Lynch, 2007, Hedge funds, credit risk transfer and fi nancial stability, Banque de France, Financial Stability Review 10, April 2007, pp. 717.

Culp, C., 2006, Structured Finance and Insurance. The ART of Managing Capital and Risk, Wiley

Duffee, G., Zhou, C., 2001, Credit derivatives in banking: useful tools for managing risk? Journal of Monetary

Economics 48, 25-54.

Eichberger, J. and M. Summer, 2005, Bank capital, liquidity and systemic risk, Working Paper

Fitch, 2005, Hedge Funds: An Emerging Force in the Global Credit Markets, 18 July 2005

Fitch, 2006, Global Credit Derivatives Survey, 21 September 2006

Franke, G., 2005, Transformation nicht-gehandelter in handelbare Kreditrisiken, Working Paper, April 2005 
Goderis, B., I. W. Marsh, J. Vall Castello, W. Wagner, 2006, Bank Behavior with Access to Credit Risk Transfer Markets, Working Paper

Grossman, S. J, 1988, An Analysis of the Implications for Stock and Futures Price Volatility of Program Trading and Dynamic Hedging Strategies, Journal of Business 61, pp. 275-98.

Hayek, F. A., 1945, The Use of Knowledge in Society, American Economic Review 35, pp. 519-530

Hellwig, M., 1998, Banks, Markets, and the Allocation of Risks in an Economy, Journal of Institutional and Theoretical Economics 154, pp. 328-435.

Hildebrand, Ph., 2007, Hedge funds and prime broker dealers: Steps towards a "best practice proposal", Banque de France, Financial Stability Review 10, April 2007, pp. 67-76

Higashio, N., T. Terada, T. Shimizu, 2006, Changes in Hedge Fund Investment Behavior and the Impact on Financial Markets. Position Concentration, Expanded Scope, and Market Liquidity Risk; Bank of Japan Review, December

IMF, 2006, The influence of credit derivative and structured credit markets on financial stability, Chapter 2 of what ???, March 2006

Krahnen, J. P., 2005, Der Handel von Kreditrisiken: Eine neue Dimension des Kapitalmarktes, CFS Working Paper No 2005/05

Krahnen, J. P. and C. Wilde, 2006, Risk transfer with CDO and systemic risk in banking, Working Paper, Universität Frankfurt

Mengle, D., 2007, Credit derivatives: An overview, Manuscript, International Swaps and Derivatives Association

Miller, Geoffrey P., 1998, On the Obsolescence of Commercial Banking, Journal of Institutional and Theoretical Economics 154, 61-77.

Morris, S. and H. S. Shin, 2004, 'Liquidity Black Holes', Review of Finance 8, pp. 118.

Morrison, A., 2005, Credit derivatives, disintermediation and investment decisions. Journal of Business, 78, 621-647.

Mustier, J.-P. and A. Dubois, 2007, Risks and return of banking activities related to hedge funds, Banque de France, Financial Stability Review 10, April 2007, pp. 85-94

Parlour, C. and G. Plantin, 2005, Credit risk transfer. Working paper, Tepper School of Business, Carnegie Mellon University.

Pastor, L. and R. Stambaugh, 2003, Liquidity Risk and Expected Stock Returns, Journal of Political Economy 111, pp. 642-685. 
Pool, F. and B. Mettler, 2007, Countdown to credit derivative futures, Futures Industry, March/ April 2007, pp. 30-38.

Rochet, J.-C. and X. Vives, 2004, Coordination Failures and the Lender of Last Resort: Was Bagehot Right After All?. Journal of the European Economic Association 2, 1116-1147.

Scholes, M. S., 2000, Crisis and Risk Management, American Economic Review 90, pp. 17-21.

Swiss National Bank, SNB, 2007, Financial Stability Report, May 2007.

Wagner, W., 2005, Interbank diversification, liquidity shortages and banking crises. Working paper, Cambridge Endowment for Research in Finance, University of Cambridge.

Wagner, W. and I. Marsh, 2004, Credit risk transfer and financial sector stability. Journal of Financial Stability 2006

Weber, A. A., 2007, Hedge funds: a central bank perspective, Banque de France, Financial Stability Review 10, Special issue on hedge funds, April 2007, pp. 161-168.

Weithers, T., 2007, Credit derivatives: Macro-risk issues, University of Chicago

Zimmermann, H., 2007, Liquidity and the financial system, Working paper (A German version was previously published as: Zur Liquidität und Sicherheit des Finanzsystems, in: Finanzmärkte: Effizienz und Sicherheit, edited by Brigitte Strebel, Schulthess, 2007, pp. 207-226) 